PAWEL GLINIAK,

\title{
FROM COLONIAL CAPITALISM TO CRONY CAPITALISM. HISTORICAL AND INSTITUTIONAL DETERMINANTS OF THE SOCIO- ECONOMIC MODEL FROM THE MALAYSIAN PERSPECTIVE
}

\begin{abstract}
During the period of colonialism the implementation of colonial capitalism resulted in the integration of Southeast Asia into the global economy, which directly influenced the local socioeconomic system. The changes occurring in the region since the 19th century, which is the period discussed in this article, can be analyzed from many points of view. The following paper focuses on the territory of present-day Malaysia, an exceptionally heterogeneous country, and it analyses the results of this transformation and the influence it had on the current socio-economic system.

Colonialism has undeniably contributed to the economic growth of the Malay Peninsula while excluding parts of the population and destroying local institutions and existing models of the socio-economic system. Despite this apparent quantitative growth, oligarchic institutions were created, impeding the area's actual qualitative socio-economic development. The decolonization process did not change it sufficiently.

The first aim of the article is to indicate the direct historical relationship between colonial capitalism, violently implemented by colonial empires in the conquered territories, and the crony capitalism formed after the decolonization period. Secondly, the author tries to identify oligarchic institutions and the outcomes of their influence. These institutions were created in the historical process within colonial capitalism and are still present today. They fundamentally influence the politics and society of contemporary Malaysia, thus inhibiting qualitative socio-economic transformation. Thirdly, the author, using a variety of indicators and indexes measuring, for example, corruption, the democratization process, or social development, seeks to demonstrate the power of crony capitalism and its institutions and their impact on impeding socio-economic development.
\end{abstract}

Keywords: Malaysia; colonial capitalism; crony capitalism; economic development; institutional economics; institutions; economic history.

\section{Introduction}

Research on the impact of the colonial period on the society and economy of developing countries is crucial for understanding the transformation of economic and social development in these countries. The burden of colonialism had introduced a new economic model - colonial capitalism, which created barriers to development. These barriers are still present today, even more than half a century after the decolonization. The amount of literature available on this socio-economic model has grown. Some of the works cited in this area include "Alien Capital: Asian Racialization and the Logic of Settler Colonial Capitalism" by lyko Day, "Egypt's Occupation: Colonial Economism and the Crises of Capitalism" by Aaron G. Jakes. Some of them are cited in this paper: "The Myth of the Lazy Native: A Study of the Image of the Malays, Filipinos and Javanese from the 16th to the 20th Century and Its Function in the Ideology of Colonial Capitalism" by Syed Hussein Alatas. There is also a growing literature on crony capitalism and its impact on economic and social development, particularly about Asia. These include "Crony capitalism, Corruption And Development In South Korea And The Philippines" by David C. Kang, „China's Crony Capitalism The Dynamics of Regime Decay" by Minxin

ISSN 1728-9343 (Print)

ISSN 2411-3093 (Online)
Pei or "Accumulation in Post-Colonial Capitalism" edited by Iman Kumar Mitra, Ranabir Samaddar, Samita Sen.

This paper aims to demonstrate how historical determinants and institutions created during the colonial period have influenced modern economic development and the model of the socio-economic system. For this analysis, the author uses the theories of institutional economics. Institutional economics and its various approaches, such as new institutional economics or neo-institutionalism, are currently thriving. Examples of fundamental writings in this area include Thorstein Veblen's pioneering "Theory of Leisure Class", "Institutional Economics" by John R. Commons, "The evolution of institutional economics: Agency, Structure and Darwinism in American Institutionalism" by Geoffrey Hodgson, "Governing the Commons: The Evolution of Institutions for Collective Action" by Elinor Ostrom, "Institutions" by Douglass North, "The New Institutional Economics" by Ronald Coase or "Economic Institutions of Capitalisms" by Oliver Williamson.

In recent decades, many studies have been dedicated directly to the institutional factors of development of particular countries, which have also popularized this school of economics. These include: "Why Nations Failed?" by Daron Acemoglu and James A. Robinson, "Institutional 
Change and Economic Development" edited by Ha-Joon Chang, "In the Shadow of Violence. Politics, Economics, and the Problems of Development" edited by Douglass North et al., and "Europe's Growth Champion," a book in which Marcin Piątkowski describes this issue from Poland's perspective.

\section{Methods of the research}

In preparing this article, the author used the method of critical analysis, the historical-comparative method, and comparative analysis. Scientific sources include Malaysian, Asian and international researchers. To see a complete picture of colonial capitalism, the period of decolonization, and crony capitalism, it is beneficial to rely on authors coming from outside the European cultural circle.

The main representative of institutional economics D. North assumed that evolving institutions significantly impact economic growth. Moreover, transforming institutions can significantly determine the course of socioeconomic life. Negative and positive effects following changes in institutions can hinder the socio-economic development. In his work "Institutions, Institutional Change and Economic Performance" North considered the role of ideas, attitudes, behaviours, beliefs or habits in economic development. In addition, he emphasized the role of institutions in the formation of patterns of behaviour (Stankiewicz, 2012: 34-35). He defined institutions and their functions in a very broad way. He believed that : (Chmielewski, 2011: 256-257; North 1991, 97):

- Institutions are systems of rules and procedures for following them, as well as moral and ethical norms designed to constrain the behavior of individuals;

- Institutions provide a framework within which human beings interact. They establish the relations of cooperation and competition that makeup society and, more specifically, its economic order;

- Institutions are at the source of rules of the game in society, or more formally, are the humanly devised constraints that shape human interactions;

- Institutions reduce uncertainty, giving structure to everyday life.

Another representative of the contemporary thoughts of institutional economics - new institutional economics, O. Williamson, treats institutions very broadly and separates them into four levels that interact with each other and overlap themselves (Chmielewski, 2011: 254-255; Woźniak-Jechorek, 2014: 399): The first two levels are analysed in this thesis.

- First level: informal institutions, i.e., customs, traditions, norms, religion, culture;

- Second level: formal institutions, i.e., constitutions, property rights, politics, bureaucracy, which define the rules of the game of economic, social and economic life;

- Third level: rules of transactions, i.e., institutions that manage, direct, regulate the economic process and "game";

- Fourth level: the sphere of economic decisionmaking, e.g., resource allocation, employment, price and production levels. The central point becomes the economic unit.

The study of the impact of formal and informal institutions on the modern economy has its practical reflection in the reports and analysis of many organizations. They examine the economy in terms of transaction costs, investment opportunities, markets and the economic environment, competitiveness, economic activity, international cooperation. They conduct studies on culture and public trust and the rule of law, corruption, or democratization. Examples of such reports are the Worldwide Governance Indicator by the World Bank. Several specific indicators examine the quality of institutions, like the Rule of Law Index, Corruption Perception Index, Index of Economic Freedom or Democracy Index.

3. The economic history of Malaysia and the formation of institutions of colonial capitalism

\subsection{Colonial capitalism}

Before the emergence of colonial states, a highly diverse region created its own socio-economic development models, which was hampered by the influence of colonial states. At the beginning of the 20th century, we can speak of two parallel realities. In the background to the activities of colonial states, the first was the traditional reality of the servants and aristocratic elites of local society. The second was exploitation-oriented colonial capitalism. The socio-political system was created and regulated by Western empires (Hirschman, Bonaparte, 2001: 9). Alatas lists the following characteristic features of colonial capitalism, the presence of which he dates from the 18th to the first half of the 20th century (Alatas, 1977: 2):

- predominant control of and access to capital by an alien economic power,

- the control of the colony by a government run by members of the alien power, acting on its behalf,

- the highest level of business, trade and industry, held by the alien dominating community,

- direction of the country's export and import trade to suit the interest of the alien ruling power,

- a bias towards the agrarian mode of production as opposed to that of industry,

- the minimal expansion of technological and scientific skill,

- the organization of production around semi-free labour,

- the absence of guilds or trade unions as a counterweight to exploitation,

- the non-involvement of large sections of the population in direct capitalist enterprise,

- the presence of a set of antitheses in the colonized society described by the term dualism.'

This system created formal and informal institutions whose main aim was to ensure the highest possible profits for the British Empire. The economic system was based on monopolies, maximum exploitation of cheap or even free labour, and the plunder of resources originally belonging to local communities. The political system was authoritarian. It legitimized racist practices based on the belief in the intellectual superiority of whites (Hirschman, Bonaparte, 2001: 9). Its foundation was Social Darwinism. Based on this idea, colonists assumed that only the Western Enlightenment could bring about modern political and social reforms or introduce economic progress. These racist theories continue to justify colonialism and its modern version as attempts to enlighten the inferior races or create exclusionary institutions (Alatas, 1977: 44-45).

From about 1760, the British Empire began to show more interest in Malaya because of its natural resources and attractive location. In 1824, under the Anglo-Dutch Treaty, Malacca and the Malay Peninsula were ceded to the British Empire. This treaty irreversibly divided Southeast Asia and not only highlighted economic differences, 
but also cultural and even linguistic differences. The administrative and political effects of this division are still visible today. They introduced formal institutions, i.e., a standardised law enforcement system, primarily based on the British law system.

As early as the 1870s, the expediting demand for raw resources, such as tin, in particular, resulted in an increasing demand for labour. In the case of the Malaya region, the vast majority of labourers came from China. As early as the 17th century, Chinese emigrants formed syndicates called kongsi. These Chinese immigrants set up an institution to manage individuals' economic activities and to regulate the social order as well as relations between the newcomers and the local rulers. The nature of this institution had a markedly conflicted character. Struggles for influence between kongsi were constant. They represented local leaders, who were often mine managers (Kaur, 2004: 48-49).

As revenue from tin mining had already become a significant part of the empire's income, the British began to realise the consequences that unrest in economically valuable areas could have. Through an agreement with the Sultan of Perak, the British established the first residencial system in Malaya, which had the characteristics of a formal institution. Similar systems were quickly introduced in Selangor, Negari Sembilan and Pahang. The British were officially supposed to have an advisory role, but de facto they managed the entire administration, except for matters relating to religion and traditional law, which remained in the sultan's hands. In addition to military protection, the sultan maintained his political status, which was important, especially in preserving the traditional hierarchy. The Europeans understood that only through indirect rule, but with the implementation of modern institutions, the key economic gains could be preserved. The residential system also in some ways consolidated the power of the sultans themselves. Until then, the fragmented local trade and population had been controlled by Malay chiefs (mal. orang kaya - rich man). Maintaining their position, military and administrative support, and the sultans' approval strengthened the position of the orang kaya in society. This enabled the British to control the entire Malay social hierarchy thus to create the elites whose role was to assist in the economic and administrative management of the occupied areas.

The residencial system contributed directly to the consolidation of a social hierarchy corresponding to British and colonial capitalism. The British gathered around the Sultan to manage the interests of the mining companies focused on tin and rubber plantations. The administrative structures created by the Empire however did not fit into the traditional Malay style of governance. From the European perspective, this was effective. According to Drabble, by the end of the 19th century tin exports from Malaysia supplied just over half the world output (Drabble, 2000: 39-40). It was then that the British became interested in the large parcel. They systematically and successively took over or leased large parts of land in all the sultanates. The commodification of land provided the opportunity to impose new taxes, which fed an inefficient administration. After these reforms the provincial local landowners had to pay a tax on their land area for the first time. The tax burden notoriously exceeded the original owners' ability to pay. As a result, with mounting debts, the land was lost to new emigrants from China or to In-

ISSN 1728-9343 (Print)

ISSN 2411-3093 (Online) dian lenders. The Malays were completely unable to cope with the new monetary economy imposed on them.

The constant need for labour for colonial capitalist needs also creating efficient exclusionary institutions. One of these was the truck system. It was created by the Chinese, who were rapidly gaining increasing economic influence. Secret Chinese syndicates widely supported the so-called towkays (mal. entrepreneurs, bosses). They provided transport, food and accommodation for new migrants from China. Exploiting asymmetry of information, they offered high-interest loans in exchange for care and assistance. The newcomers, who were then used as cheap labour, were unable to repay the loans. Thus, they went into debt and consequently tied themselves to their towkay legally and financially, becoming de facto slaves. The result was a typical institution based on the peonage system (Andaya, Andaya, 1982: 160-161, 177).

Another consequence of the residential system was the introduction and growth in the importance of money capital in the region's economy. It was used for long-term investment in assets and short-term financing of corporate operations. One example of the exclusionary institutions thus created was the so-called revenue farming as a specific financial management technique. The reason for the introduction of this institution was the sultan's inability to tax Chinese settlers directly. It allowed people to buy from the government and gave the ruler the right to collect taxes in a fixed period, for goods in high demand, such as alcohol, opium or even gambling proceeds. The most frequent beneficiaries of this opportunity were wealthy Chinese, who collected taxes from local Malay communities. Next to them, the biggest beneficiary of this system was the British. The funds collected led to extraordinary domination of a narrow group of Chinese entrepreneurs in the mining industry (tin) and allowed for subsequent diversification of investments into the production of more technologically advanced goods, trade or banking. On the other hand, however, this has led to growing wealth inequality between and within ethnic groups (Drabble, 2000: 56).

Because of the need to unify land management, labour, taxation or logistical issues between areas, the British decided to federalise the Malay states. In 1895, they signed treaties with all four Malay sultanates: Selangor, Perak, Negari Sembilan and Pahangu and the Federated Malay States (FMS) were established. As Andaya and Andaya point out, the traditional Malay rulers did not realise the consequences of these changes, which resulted in a drastic decline in their importance. The role of the sultanates became almost entirely ceremonial and symbolic (Andaya B., Andaya L., 1982: 183).

One of the most significant formal institutions taken from the West was Torrens system of regulations, which introduced procedures for registering titles over land. It assumed that an official system would administer land rights under the control of the empire. In addition, every transaction involving land was to be registered. This resulted in the final transfer of control over land in the federated states from the traditional rulers - the sultans - to the colonisers.

In evaluating the socio-economic development of Malaya at the time, scholars point to the increasingly accentuated inequalities between the Malay people and their elites. Debt, which shaped social relations, played a major role here. It is true that in the 1880s representatives of the British Empire cancelled the debts of slave labourers 
in the colonies, but paradoxically the situation of the previously indebted population did not improve. This was because landowners, who had hitherto exploited slave labour, were no longer obliged to provide shelter and food for those freed from the burden of debt. The former slaves did not own land and the wages offered were extremely low by the end of the 19th century. The district administrators of the time, like the peasants, had also lost their sources of income. Nevertheless, it has been indicated that life in the provinces and the living conditions of those making a living from agriculture were not totally hopeless (Drabble, 2000:114).

Another informal institution, the so-called free port mentality, became a barrier to the industrial development of the Malays of the time. In the public interest and an influential group of businessmen and administration, it was important to preserve the traditional free port status and continue to concentrate on the export of raw materials. In the four decades between 1875 and 1915, the volume of exports increased more than seventeen fold (Lafaye de Micheaux, 2017: 38). The export of tin, rubber and other raw materials was extremely profitable. In addition, the extraction of raw materials required huge amounts of labour and at the same time brought a satisfying income. It was seen as irrational and inefficient to shift labour to develop sectors that were higher in risk in comparison. Data shows that in 1931, when the Malay economy recorded its highest level of exports, only $12.7 \%$ of the population worked in manufacturing (Drabble, 2000: 136-137).

Colonisation shaped the economy and the narrative of norms and traditions associated with society's culture and value system. Colonial conquest did not only involve the shaping of formal institutions, such as laws to ensure the effective plunder of the colony but also engaged in changing informal institutions. As Shamsul points out, in a slow but steady process, the colonisers interfered with the local mental models and their perception of the social and natural world, thus increasingly depriving the natives of the possibility to define their world. Consequently, local institutions were replaced by Western ones (Shamsul, 2001: 357).

Alatas emphasises that from the documents wrote by Western observers, an image emerges of a gullible and seemingly polite Malay: sensitive to insults, violent, explosive. Colonialists saw Asians as an inferior type of people. The British described the Malays as not inclined to hard, incessant work, and their characteristics were well suited to servants who had to perform simple, unambiguous tasks. The attitude towards the labour by the Malays is also negative in this account. They are a lazy and idle-loving group, lacking creativity and the ability to think abstractly or desire to enrich themselves. They are untrustworthy, treacherous and devious, and show loyalty only to patrons from their own society. Similarly, Western authors have described the Chinese as savage and unscrupulous or the Indians trying to cheat at every turn (Alatas, 1997: 44-45, 114-115).

Despite the obviously racist nature of such thoughts, it is also linked to the fact that colonial authorities based on this knowledge could adopt policies or institutions to suit the 'character' of colonial society. This perpetuated for decades the lack of self-esteem in Malays as inferior individuals. Modern Malay identity has its foundations in the colonial period and is orientalist-colonial in nature. The racist narrative present during the colonial period has shaped the mutual perceptions of the different ethnic groups and influenced the culture and institutions of modern Malaysia (Shamsul, 2001: 357).

\subsection{World War II and decolonization}

British Malaya was attacked by Japan on 8 December 1941 and was quickly defeated. The Japanese administration had a specific policy towards the people of the occupied areas depending on their ethnicity. To win over the Malay masses, the Japanese occupier played the nationalist card by rapidly increasing the powers of the Sultan and organising all kinds of demonstrations and marches or conferences of an ethnic-nationalist nature. The Japanese occupation contributed significantly to the impoverishment of Malaysian society and the destruction of the region's economy. Exports were focused solely on the needs of the Japanese war machine. The local population, on the other hand, tried to be as self-sufficient as possible (Andaya, Andaya, 1982: 248).

After the war, the British Empire sought to ensure a capitalist system and institutional order in preparing to cede power. This was to ensure the development and stability of a multi-ethnic post-colonial state with the parallel political influence of Britain. They feared communist or radical leftist guerrillas who might take control, especially the countryside, as happened a few years later during the Darurat Malaya uprising in 1950. Malaysia at that time was regionally one of the most resilient economies, reaching a GDP per capita at the level of Japan. The British were also concerned about the intensification of ethnic conflicts, particularly between Malay and Chinese. In early 1946 Malayan Union was formed, whose system was based on a capitalist economy with a democratic government that granted citizenship to all ethnic groups. Malays and Chinese and Indians who had been born in or resided in Malaya ten of the fifteen years before 1942 (Tajuddin, 2012: 101-102).

Initially, the British were skeptical about the idea of creating an axis of political conflict running between ethnic groups. However, the 1955 elections demonstrated the efficiency of this system from a political perspective and the distribution of parliamentary seats along ethnic lines. UMNO (United Malays National Organisation) fully represented this policy, a coalition bloc of parties bringing together the three most important ethnic groups. On the one hand, ethnic-based political representation ensured stability; on the other, this representation was provided by pro-Western, free-market-oriented elites. Thus Britain's economic interests were protected. The westernised elites of all ethnic groups realised that only consolidation of power and cooperation could bring about national development and peace in this extremely diverse country.The Federation of Malaya (later Malaysia) achieved independence on 31 August 1957.

\subsection{The modern economy and crony capitalism}

Decolonisation brought economic transformation, the expulsion of empires and the dismantling of colonial capitalism. However, the institutions and the historical determinants created crony capitalism (see Graph 1). It can be defined as a market economy system in which those close to political authorities who make and enforce rules receive economic favors that enable them to earn returns above what would prevail if factors were priced by the market (Limoeiro, 2020: 12). 

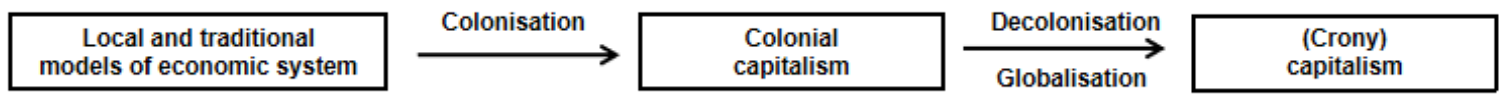

\section{Graph 1. A Simplified model of the economic system in the region (Source: own elaboration).}

Together with the Malay elites, the British attempted to pursue a model that would ensure the increased industrialisation of the country while preserving their vested interests. In 1958 the government adopted the recommended suggestions of the World Bank and in 1960 introduced a programme of investment incentives for foreign corporations. This can be seen as the beginnings of crony capitalism in Malaysia. Investments are supposed to develop automotive, electronics and textile industries. Because the government subsidised foreign corporations, the number of companies with a majority of foreign capital among all the largest enterprises in Malaysia increased from $38.5 \%$ in 1959 to $60.7 \%$ in 1970 . In such sectors as agriculture, extraction of raw materials or trade, we can speak of foreign-owned companies' hegemony. Evidently threatened, Chinese entrepreneurs closed in on their own group and exploited their own business development opportunities mostly in construction or trade. During this period, Malay businesspeople, lacking capital and experience, could not find their way into the new reality (Hirschman, 1998: 77).

During the first decade of independent Malaysia, economic development was limited. However, the policies pursued resulted in rapid economic growth rates of about $6 \%$ per annum. In parallel relatively little reduction in absolute poverty levels was noted. The poor, especially the Bumiputera living in the province, remained in the traditional economic system, characterised by low productivity and low value-added goods. Foreign corporations were the main beneficiaries of growth, followed by Chinese entrepreneurs. The income gap between rural and urban households also widened. Widespread poverty was accompanied by high unemployment, which reached $8 \%$ by the end of the period. This contributed to increasing income inequality and caused even more frustration for most of the population, mainly ethnic Malays (Ragayah, 2014: 21).

In 1969, anti-Chinese riots erupted, the causes of which could be traced to both inter-ethnic wealth disparities and the fueling of sentiments by Malay politicians and activists. The aftermath of the riots was the introduction of the New Economic Policy - NEP (mal. Desar Ekonomi Baru - DEB) in 1970. This policy lasted until 1990 as a programme for economic and national development in a multi-racial society. The NEP had two main objectives. The first was to reduce and further eradicate poverty by increasing income and creating employment opportunities for the entire population. This objective focused mainly on the poorest ethnic group, the Bumiputera. The second objective was to change the structure of society. An attempt was made to redefine the different ethnic groups' existing roles in the economic system.

Malaysia abandoned the laissez-faire policies it had pursued since the 1950s favoring more active state intervention by introducing licenses, quotas, or regulated prices. The government created free trade zones and supported the establishment of licensed workshops and factories. The implemented policies aimed to encourage producers to export manufactured goods (Ragayah, 2008: 122-123). The New Economic Policy implementation can be considered the birth of the modern Malaysian economy (Lafaye de Micheaux, 2017: 152). The NEP brought about a remarkable socio-economic transformation of the country. There has been an impressive reduction in poverty both among ethnic groups and between rural and urban areas. Poverty among the Bumiputera fell by 41.8 p.p. over the two decades of DEB implementation and by 2014 this problem could be considered eliminated (poverty level of $0.8 \%$ ) (see Table 1). The real economic miracle was particularly evident from 1988 to the Asian financial crisis in 1997, when the Malaysian economy achieved growth of $10 \%$ per annum (Economic Planning Unit, URL...). The NEP's success continued under the National Development Policy - NDP (mal. Dasar Pembangunan Nasional, DPN) programme was implemented from 1991 to 2000, with the priority objective of achieving a standard of living for Malaysians similar to economically developed countries. The most visible effect was increasing the level of socio-economic development among the underprivileged, especially Bumiputera, through affirmative action.

Table 1. - Poverty rate by ethnic group and area in Malaysia, 1970-2019

\begin{tabular}{|l|c|c|c|c|c|c|c|c|c|c|c|c|}
\hline & 1970 & 1976 & 1979 & 1987 & 1989 & 1995 & 1999 & 2004 & 2009 & 2014 & $2016^{*}$ & $2019^{*}$ \\
\hline Malaysia & 49.3 & 37.7 & 37.4 & 19.4 & 16.5 & 8.7 & 8.5 & 5.7 & 3.8 & 0.6 & 7.6 & 5.6 \\
\hline Bumiputera & 64.8 & 46.4 & 49.2 & 26.6 & 23 & 12.2 & 12.3 & 8.3 & 5.3 & 0.8 & 9.7 & 7.2 \\
\hline Chinese & 26.0 & 17.4 & 16.5 & 7.0 & 5.4 & 2.1 & 1.2 & 0.6 & 0.6 & 0.1 & 2.2 & 1.4 \\
\hline Indian & 39.2 & 27.3 & 19.8 & 9.6 & 7.6 & 2.6 & 3.4 & 2.9 & 2.5 & 0.6 & 5.5 & 4.8 \\
\hline Urban population & 21.3 & 15.4 & 17.5 & 8.5 & 7.1 & 3.6 & 3.3 & 2.5 & 1.7 & 0.3 & 4.8 & 3.8 \\
\hline Rural population & 58.7 & 45.7 & 45.8 & 24.8 & 21.1 & 14.9 & 14.8 & 11.9 & 8.4 & 1.6 & 17.5 & 12.4 \\
\hline
\end{tabular}

* Since 2016, the poverty line in Malaysia has been changed from 980RM to 2208RM.

Source: Household Income, Poverty and Household Expenditure, URL: http://epu.gov.my/en/socio-economicstatistics/household-income-poverty-and-household-expenditure, (Accessed: 27.12.2020) 
The Asian financial crisis was a significant event from the perspective of the economies and the societies of Southeast Asia. It is not uncommon for scholars to identify the causes of the crisis in the fragility of informal institutions, especially the client-patron relationship. This exclusionary institution's roots can be traced back to feudal times and consolidated during colonial capitalism. The crisis hit in a situation where the local rich elite, due to the cultural and social norms, was practically not subject to any control by society. Their relations with the government were based largely on corrupt links. As in colonial times, these elites became the beneficiaries of incoming foreign capital (Sowa, 2008: 15-17). The causes of the crisis can also be traced to the Chinese business model prevalent in Southeast Asia. This mainly concerns the control over large corporations by individual families, often of Chinese origin, the lack of distinction between ownership and management of a given company, close investor relations with banks (Rasiah, 2010: 110). During the crisis, the government chose not to implement the orthodox policies suggested by international organisations like IMF. It balanced between neo-liberalism and statism. It was quite successful, especially when comparing the results of individual countries in the region, such as Thailand and Indonesia, where we can still see the consequences of that economic actions today (Gliniak, 2016: 77-79).

Close relationships between government and private companies were common. Not infrequently these relations were of an obscure nature, as people from the circles of power, usually a very exclusive group, influenced the company's management. Popular opinion among investors, including foreign ones, was that such an arrangement guaranteed the solvency of a given company. Thus, financiers saw an investment opportunity for granting loans, regardless of the actual financial situation of the company. Such an arrangement also guaranteed the granting of state subsidies and created and protected monopolies. It is believed that the political relationship with business, which contributed to the misallocation of investment and thus a decline in returns on capital, resulted in a drastic decline in foreign investors' confidence in the markets of the region (ILO Regional Office for Asia and the Pacific, 1998: 11).

The level of corruption is measured by many indicators, including the Corruption Perception Index (CPI). After UMNO's defeat in the 2018 elections, the new government has strengthened the fight against corruption and is trying to improve transparency in lawmaking, tendering or budgeting (Durairaja, 2019: 9). This has contributed to the improvement of this indicator. According to the 2019 data, Malaysia ranks 57th out of 180 countries analysed with a 51/100 and has seen a drop of six places compared to 2019 (Transparency International, URL...). In popular opinion, it may seem that Malaysians accept corruption if it can benefit them. This is somewhat confirmed by the World Values Survey conducted in 2018. As many as $42.4 \%$ of survey participants indicated that it is always or often the case for them to pay a bribe, give a gift or do a favour to local officials to deliver services. At the same time, as many as $22.8 \%$ of Malaysians indicated that giving bribes is justified to some extent. This is much higher than countries in the region. For Thailand this figure was only $2.8 \%$ and for Indonesia $-7.1 \%$ of respondents (World Values Survey, URL...).

Corruption in politics is a real threat and can lead to a decline in confidence in the democratisation process.
Some wealthy Malaysian businesses owe their growth to preferential treatment from the government. About onefifth of companies that applied for building permits expected to have to pay a bribe during visits with officials. In addition, about $40 \%$ of firms said that corruption was a moderate if not a major obstacle to their ongoing business activities. About $11 \%$ of total annual sales had informal gifts or payments to government officials to "get things done" to be distributed. The researchers note that due to the declarative nature of the responses, the actual degree of corruption may be much higher (Yusof, Arshad, 2020: 12).

Between 2001 and 2010, the government introduced the National Vision Policy - NVP (DWN, mal. Dasar Wawasan Negara). The NVP contained all the previous development goals and issues outlined in the NEP and NDP. It included several main points, including building a strong, tolerant and just society by promoting social cohesion and reducing poverty and inequality between ethnic groups and regions. Attention was also given to developing human capital and creating a better-educated workforce. Today, Malaysia is in a key phase of economic transformation under the Vision 2020 (mal. Wawasan 2020) plan. The overarching goal of Wawasan 2020 was to have Malaysia join the group of developed countries by 2020. Despite isolated bumps associated with crises, Malaysia's economy has continued to grow rapidly, achieving growth of $5 \%$ between 2001 and 2018, excluding 2009. The HDI between 1990 and 2018 increased from 0.644 to 0.804 (United Nations Development Programme, URL...). However, it should be remembered that once a certain level of GDP is reached, with this nature of the economy, there is the problem of the middle-income trap that the country is currently facing (Lafaye de Micheaux, 2017: 149-150, 178).

3.4 Malaysia's contemporary economy and the quality of its institutions

An empirical assessment of the contemporary economy can also be made from the perspective of evaluating institutions, especially those most affected by crony capitalism. Formal institutions that negatively influence social cohesion have their roots in the colonial system, including the division of the political scene along ethnic lines. On the one hand, the constitution's design has been influenced by the colonial past and the institutional conditions associated with it; on the other hand, a significant influence of Asian values can be seen. There are clear differences between the Western, liberal view of human rights and the rights in The Federal Constitution of Malaysia. Only nine articles are devoted to these human rights issues, which are very general in nature.

Various exclusionary institutions also contribute to the distortion of democracy in Malaysia. These include informal institutions associated with Asian values, such as hierarchy, and formal institutions, such as authoritarian laws, which have their roots in colonial times. This leads to the radicalisation of the Malay majority and the disintegration of the multi-ethnic society. Despite considerable progress in recent years, linked to the 2017 general election and the imposition of a state of emergency and suspension of parliament during the COVID-19 pandemic (The Diplomat, URL...). Malaysia is considered a "flawed democracy" by The Economist Intelligence Unit, which produces Democracy Index reports, and ranks 39th in 2020 (see Graph 2) (The Economist Intelligent Unit, URL...). 


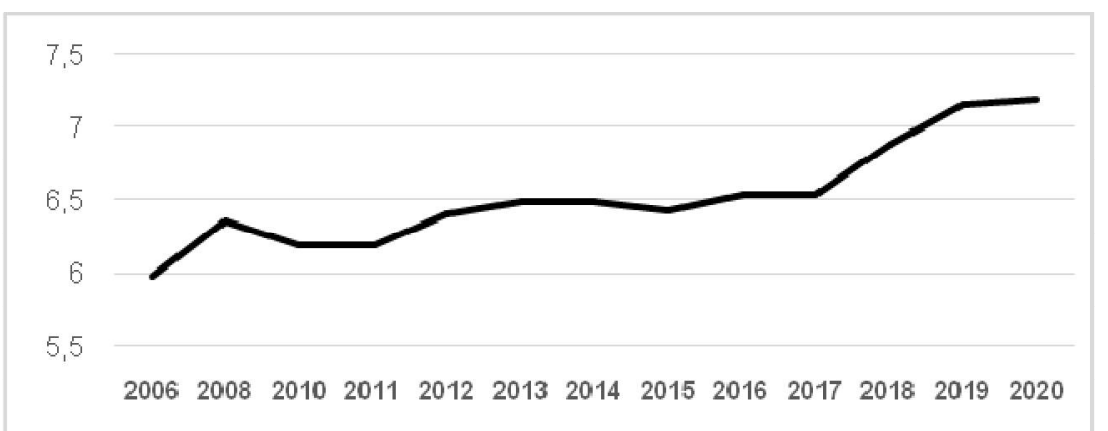

Graph 2. Democracy Index 2006 - 2020, Malaysia.

(Source: The Economist Intelligence Unit, Democracy Index 2020: In sickness and in health?,

URL: https://www.eiu.com/n/campaigns/democracy-index-2020 (Accessed 10.07.2021)).

The situation is similar when it comes to freedom of expression. Although the eleventh article of Malaysia's constitution indicates that every person has the right to follow their own religion, in practice this right is violated. Freedom of religion is a component of the Social Progress index. For 2019, Malaysia ranks only 117th globally in this category, despite its overall score being 49th out of 149 countries assessed (2020 Social Progress Index, URL...). Freedom House also has many concerns on this issue. In 2019, Malaysia's civil rights score according to this research institution had admittedly improved, but this has not been affected by the religious freedom component of the index. The country scores 31 out of 60 in this category, and such a low score is mainly related to the dominance of Islam over other religions and its influence on the country's politics (Freedom House Report 2019 Malaysia, URL...).

Also, part of the assessment of democratic institutions is media freedom, suppressed in Malaysia. However, with the recent change of power, the situation is improving. In the press freedom ranking organized by the international NGO, Reporters Without Borders, Malaysia ranks higher than in 2020, but still ranks 119th. In recent years, Malaysia has ranked between 123rd and 147th out of 180 countries analyzed (2021 World Press Freedom Index, $U R L$...). The government still has authoritarian laws that can restrict media freedom and freedom of expression, for instance the 1998 Communications and Multimedia Act; the 1984 Printing Presses and Publications Act, the 1972 Official Secrets Act, and the 1948 Sedition Act. Authorities have the power to search editorial offices, have strict control over publishing licenses, and journalists can be sentenced to 20 years in prison on charges of sedition and anti-government activities. These restrictions pose a constant threat to journalists who, despite relative progress in the area of freedom of expression made in recent years, cannot work with full freedom (Reporters Without Borders (RSF), URL...).

The high level of corruption in the country is linked to the lack of an independent judiciary and legislature. The level of corruption is high, especially among the elite consisting of politicians, business people and officials. According to reports, $43.7 \%$ of those arrested for corruption were public officials, $13.4 \%$ were businessmen and $1.4 \%$ were politicians (Durairaja, 2019: 3). A feature of the Malaysian public sector is the close relationship between the political class and civil servants. As a result, the position of the administrative and political elite in Malaysia is considered disproportionately high compared to countries with mature democratic systems (Chin, 2011: 148, 150151). The patronage mechanism has resulted in a corrupt and inefficient administration that affects ordinary citizens.

\section{Conclusions}

As the author shows, Malaysia's economic history clearly demonstrates that the formal and informal institutions created under colonial capitalism, despite the revolutionary change in the economic model during decolonization, continue to influence society and the economy all the time. Political and business elites have created oligarchic institutions. The overarching goal of any institutional change should be to achieve inclusive socio-economic development. Economic change cannot be achieved in a vacuum. Despite an increase in Democracy Index (Graph 2.) or a reduction in corruption, democratization needs to be accelerated. Laws that have their roots in colonial capitalism, that suppress personal freedoms should be quickly removed. The apparent change in the ruling party after the 2018 Malaysian General Election has not led to significant changes in the composition of these elites. There is still a lack of proper reform of state organizations and a change of personnel that would eliminate clientelism and nepotism, curbs corruption and as resulted crony capitalism. The democratic institutions present in the country need strengthening, both at the national, state and local levels. Policymakers should also not forget the relevance of civil society and NGOs in social control of power, which plays a key role in countries with mature democracies. Malaysia, to ensure social cohesion for all Malaysians, should end politics based on ethnic division. Unfortunately, neither the years of the infamous Prime Minister Najib Razak, nor the recent period of Mahathir Mahomad's and later Muhyiddin Yassin rules shows no real attempt at change. In the second half of 2021, Malaysia undergoes another political crisis that is the aftermath of the pandemic, but also of institutional failure.

Rapid growth has been present in Malaysia for at least several decades. It has resulted in a significant decrease of poverty level (Table 1.) and inequality among the entire population and all ethnic groups. Its foundations can be traced back to the formal institutions inherited from the British and successful economic reforms, includ- 
ing implementing the NEP. 2010s led to large-scale social and cultural change It has produced a modern, westernized civil society capable of contesting the current "managed democracy", old elites and institutions. However, this needs a strong opposition, not only parliamentary, but also a developed civil society. This will make it possible to eliminate, or radically reduce, the influence of ethnic considerations in politics on the economic and social objectives adopted and formulate progressive, democratic, and inclusive principles for developing a multiethnic Malaysian society. This development continues to be hampered by mutual bickering and resentment not only on personal, but also on ethnic and religious grounds. However, as the numerous pro-democracy protests showed, the undermining of social hierarchies is becoming the norm. Economic growth has produced a stronger and more aware and united middle class which has become the hope and the future of the country.

\section{REFERENCES}

Andaya, B. \& Andaya, L. (1982). A History of Malaysia, MacmilIan Education UK, London.

Alatas, S. H. (1997). The Myth Of the Lazy Native, Frank Cass and Company Ltd., London.

Chmielewski, P. (2011). Homo agens, Institutionalism in the Social Sciences, Poltext, Warszawa, (In Polish).

Chin, J. (2011). History and Context of Public Administration in Malaysia, (in:) Public administration in Southeast Asia, Berman E. (eds.), Taylor and Francis Group, London, pp. 29 52.

Drabble, J. (2000). An Economic History of Malaysia, c. 18001990. The Transition to Modern Economic Growth, Palgrave Macmillan UK, London, 2000.

Durairaja, S., et. al. (2019). Corruption in Malaysia A Review, Indian Journal of Science and Technology, vol. 12, no. 24, s. $1-12$.

Gliniak, P. (2016), The Washighton Concensus And The Experience Of Malaysia And Indonesia During The Asian Financial Crisis, Ekonomia XXI Wieku, vol. 9, nr 1, s. 65-79.

Hirschman, Ch. (1998). Ownership and control of the Malaysian economy revisited: a review of research in the 25 years since the publication of J.J. Puthucheary's classic', (in:) Puthucheary D., Jomo K.S. (eds.), No Cowardly Past: James J. Puthucheary Writings, Poems and Commentaries, INSAN, Kuala Lumpur, Malezja, s. .71-83.

Hirschman, Ch., Bonaparte, S. (2001). Population and Society in Southeast Asia: A Historical Perspective, (in:) Demographic Change in Southeast Asia: Recent Histories and Future Directions, Williams L., Guest Ph., (eds.), Southeast Asia Program Publication at Cornell University, Ithaca, NY, pp. 5-42.

Kaur, A. (2004). Wage Labour in Southeast Asia since 1840. Globalization, the International Division of Labour and Labour Transformations, Palgrave Macmillan, London.

Lafaye, de Micheaux E. (2017). The Development of Malaysian Capitalism. From British Rule to the Present Day, IRD, Kuala Lumpur.

Lim, Ch. Y. (2001). Southeast Asia: The Long Road Ahead, World Scientific Publishing Company, Singapore.

Limoeiro, D. (2021). Economic Growth, Inequality and Crony Capitalism, The Case of Brazil, Routledge, New York.

North, D. C. (1991). Institutions, The Journal of Economic Perspectives, Vol. 5, No. 1, s. 97-112.
Ragayah, H. (2008). Income inequality in Malaysia, Asian Economic Policy Review, vol. 3, no. 1, s. 114-132.

Ragayah, H. (2014). Malaysian Development Experience: Lessons for Developing Countries, Institutions and Economies, vol. 6 , no. 1, s. 17-56.

Rasiah, R. (2010). Industrialization in the second- tier NIEs, (in:) The New Political Economy of Southeast Asia, Rajah R., Schmidt J. D. (eds.), Edward Elgar, Cheltenham, s. 44 - 102.

Shamsul, A. B. (2001). A History of an Identity, an Identity of a History: The Idea and Practice of 'Malayness' in Malaysia Reconsidered, Journal of Southeast Asian Studies, vol. 32, s. $355-366$.

Sowa, J. (2008). Enjoy your late grandchildren! Colonialism, globalisation, and radical democracy, Wydawnictwo Ha! art, Cracow. (In Polish)

Stankiewicz, W. (2012). Institutional Economics. Lecture outline, Wydawnictwo Prywatnej Wyższej Szkoły Businessu i Administracji, Warsaw. (In Polish).

Tajuddin, A. (2012). Malaysia in the World Economy (18242011): Capitalism, Ethnic Divisions, and "Managed" Democracy, Lexington Books, Lanham.

The Social Impact of the Asian Financial Crisis, ILO Regional Office for Asia and the Pacific, Bangkok, 1998.

Woźniak-Jęchorek, B. (2014). J.R. Commons vs. O.E. Williamson - two institutional schools and their achievements from a labour market economics perspective, Studia Prawnoekonomiczne, vol. 92 (In Polish)

Yusof, S. A., Arshad, M. (2020). Estimations of business exposure in corruption in Malaysia, Journal of Financial Crime, vol. 27 , no. 4 , s. $1273-1287$.

\section{LIST OF REFERENCE LINKS}

2020 Social Progress Index Malaysia, URL, https://www.socialprogress.org/?tab=2\&code=MYS, 07.01.2020 (Accessed 10.07.2021)

2021 World Press Freedom Index, URL: https://rsf.org/en/ranking, (Accessed 04.01.2020).

Economic Planning Unit, Household Income, Poverty and Household Expenditure, URL: http://epu.gov.my/en/socioeconomic-statistics/household-income-poverty-andhousehold-expenditure, (Accessed 27.12.2020)

Freedom House Report 2019 Malaysia, URL: https://freedomhouse.org/report/freedom-world/2019/malaysia, (Accessed 07.01.2020).

United Nations Development Programme, Human Development Report 2020, Malaysia, URL: http://hdr.undp.org/sites/all/themes/hdr theme/country-notes/MYS.pdf, (Accessed 01.01.2020).

Reporters Without Borders (RSF), The situation of the press freedom in Malaysia, URL: https://rsf.org/sites/default/files/rsf upr malaysia.pdf, (Accessed: 04.01.2020).

Transparency International, Corruption Perception Index 2019, Malaysia. URL: https://www.transparency.org/en/cpi/2019/results/mys\#details (Accessed: 7.11.2020).

The Diplomat, Malaysia's PM to Decide on Parliament Return as Pandemic Worsens. URL: https://thediplomat.com/2021/07/malaysias-pm-to-decide-on-parliament-return-aspandemic-worsens/ (Accessed: 10.07.2020)

The Economist Intelligence Unit, Democracy Index 2020: In sickness and in health?, URL: https://www.eiu.com/n/campaigns/democracy-index-2020 (Accessed 10.07.2021).

World Values Survey Wave 7: 2017-2020. Questions 118 \& 181. URL: $\quad$ http://www.worldvaluessurvey.org/WVSOnline.jsp, *Accessed: 23.12 .2020 ) 
Павел Гліняк,

Вроилавський економічний університет (м. Врочлав, Польща)

e-mail: Pawel.Gliniak@ue.wroc.pl,ORCID 0000-0001-8463-4710

\section{ВІД КОЛОНІАЛЬНОГО ДО ХРОНІЧНОГО КАПІТАЛІЗМУ. ІСТОРИЧНІ ТА ІНСТИТУЦІЙНІ ДЕТЕРМІНАНТИ СОЦІАЛЬНО-ЕКОНОМІЧНОЇ МОДЕЛІ З МАЛАЙЗІЙСЬКОї ТОЧКИ ЗОРУ}

У період колоніалізму впровадження колоніального капіталізму призвело до інтеграції ПівденноСхідної Азії у світову економіку, що безпосередньо вплинуло на місцеву соціально-економічну систему. Зміни, що відбулися в регіоні 3 XIX століття (саме цей період досліджується в статті), проаналізовано 3 багатьох точок зору на прикладі такої неоднорідної країни, як сучасна Малайзія. Автор показує, що колоніалізм, безперечно, сприяв економічному зростанню Малайського півострова, але залученою до цих змін виявилася лише частина населення, при цьому було зруйновано місцеві інститути та існуючі моделі соціально-економічної системи. Незважаючи на очевидне кількісне зростання, утворилися також олігархічні інститути, які перешкоджали реальному якісному соціально-економічному розвитку регіону. Процес деколонізації не змінив його в достатній мірі.

Обґрунтовано прямий історичний зв'язок між колоніальним капіталізмом, насильно впровадженим колоніальними імперіями на завойованих територіях, та хронічним капіталізмом, що утворився після періоду деколонізації. Охарактеризовано олігархічні інститути та результати їх впливу. Показано, що ці інституції були створені в історичному процесі в рамках колоніального капіталізму і вони до сьогодні мають суттєвий вплив на політику та суспільство сучасної Малайзії, гальмуючи, таким чином, якісні соціально-економічні перетворення. Прагнучи продемонструвати силу інститутів хронічного капіталізму та їх гальмівний вплив на соціально-економічний розвиток країни, автор використовує різноманітні показники та індекси, що вимірюють корупцію, процеси демократизації чи суспільного розвитку.

Ключові слова: Малайзія; колоніальний капіталізм; хронічний капіталізм; економічний розвиток; інституційна економіка; інститути; економічна історія.

(C) Pawel Gliniak

Надійшла до редакції: 13.07.2021

Прийнята до друку: 06.08.2021 